\title{
Testing yardstick competition through a vote-function: evidence from the Walloon municipalities
}

\author{
Laurent Van Malderen $^{1^{*}} \cdot$ Marcel Gérard ${ }^{2}$ \\ ${ }^{1}$ Louvain School of Management, Université Catholique de Louvain, Belgium \\ ${ }^{2}$ Louvain School of Management, Université Catholique de Louvain, Belgium; Idep, CESifo and Ires
}

\begin{abstract}
This paper aims at testing yardstick competition among the local jurisdictions of the Walloon Region (Southern part of Belgium) by directly testing its seminal hypothesis: yardstick voting. Actually the theory states that local incumbents are mimicking each other because they fear punishment for implementing higher tax rates than in neighbouring jurisdictions. Our research question is whether voters punish their incumbents for higher tax rates.

We estimate different specifications of a vote function. None of them supports the yardstick voting hypothesis. One can thus exclude yardstick voting being statistically supported by taxpayers' behaviour. And we can exclude yardstick competition as a source of tax interactions in the region if yardstick voting is a testable hypothesis of yardstick competition. Indeed, if tax rates of the neighbouring jurisdictions do not influence voters' choices, incumbents do not have to fear an electoral punishment and then mimicking each other is meaningless.
\end{abstract}

Keywords: yardstick competition, vote-function, elections

JEL Classification Codes: C21, H71, R50

\section{Introduction}

Yardstick competition is one of the main theoretical sources of interactions among local jurisdictions. According to this theory, voters are evaluating the performance of their incumbents by using information on the tax rates of neighbouring jurisdictions (Santolini, 2008). The reason for this behaviour is that they do not know the level of public services a given tax level can provide (Elhorst and Fréret, 2009). Hence, other jurisdictions can serve as a benchmark for

*Corresponding author. E-mail: laurent.vanmalderen@uclouvain-mons.be.

Citation: Van Malderen, L. and M. Gérard (2013) Testing yardstick competition through a vote-function: evidence from the Walloon municipalities, Economics and Business Letters, 2(4), 206-214. 
voters. Doing so voters can identify 'good' and 'bad' politicians and re-elect only those they judge as 'good' (Besley and Smart, 2007). Incumbents being aware of this behaviour, representatives may anticipate this yardstick mechanism and adapt their policies to those of their neighbours (Feld et al., 2003).

This theory has mainly been tested through the estimation of a tax reaction function, where the optimal tax rate in a jurisdiction depends on the tax rates in nearby jurisdictions (Revelli, 2005). However, the yardstick competition theory provides another testable hypothesis. One can test whether incumbents are punished for tax increases, and then whether the electoral punishment depends on tax rates in neighbouring jurisdictions (Vermeir and Heyndels, 2006). In that case, one talks about comparative or yardstick voting (Salmon, 2013). Thus, one tests directly the seminal hypothesis that is underlying yardstick competition. Despite this advantage, the research literature which uses this approach is scarce as the literature review on yardstick competition of Delgado et al. (2011) shows.

Hence, the aim of this paper is to test yardstick competition among the local jurisdictions of the Walloon Region (Southern part of Belgium) along that line. To achieve this objective, we estimate a vote-function using cross-sectional data on the results from the most recent local election which took place in Belgium. It is, to our knowledge, the first time a vote function is estimated for the Walloon Region. It is well-adapted for such an analysis as all local jurisdictions are institutionally homogeneous and share identical competences (Richard et al., 1997). In addition, the main local taxes account for more than 40 percent of local revenues and are freely determined by policy makers (Heyndels and Vuchelen, 1998). Finally, elections took place in the same day in every jurisdiction, which makes easier tax rates comparisons by voters.

\section{Methods}

One can estimate a popularity/vote function or the probability of re-election/defeat of incumbents in order to test for yardstick voting. We choose the former approach because of the system of proportional representation that is in force in the Walloon Region. Each list gets municipal councillors in line with the number of votes obtained (Gérard and Van Malderen, 2012). A majority contract is then passed between the lists that want to work together and whose sum of councillors exceeds half the total number of councillors. It follows from this system that incumbents can get the same electoral results than in the previous election but not be re-elected because of a different arrangement between the parties of the majority contract.

Let $V_{t}$ be the vector of (sum of) vote share(s) obtained at the election year $t$ in Walloon municipalities by the party (parties in case of coalition) that was (were) in government in these municipalities during the legislature that came to an end. This vote share is depending on economic, political and budgetary variables (Vermeir and Heyndels, 2006).

Two different specifications have been used in the empirical literature. Bordignon et al. (2002), Vermeir and Heyndels (2006) and Dubois and Paty (2010) use the tax variables in level. We will name it the "level I" model. It is written:

$$
V_{t}=\alpha V_{t-1}+\mathbf{X}_{t} \beta+\delta T_{t}+\lambda \mathbf{W} T_{t}+\gamma N_{t}+\varepsilon_{t}
$$

where $V_{t-1}$ is a vector of vote shares at the previous election that expresses a long-term strength or vote inertia (Dubois and Paty, 2010), $\mathbf{X}_{t}$ is a matrix of socio-demographic variables, $T_{t}$ is a vector of tax rates of municipalities at time $t$, and $\varepsilon_{t}$ is the error term which is assumed to be i.i.d. 
distributed. $\mathbf{W}$ is a spatial weight matrix that describes the spatial arrangement of the jurisdictions in the sample (Elhorst and Fréret, 2009). This arrangement can be based on a strict geographical criterion (e.g. contiguity weight matrix) or on demographic and geographic criteria as in Dubois and Paty (2010). In this paper, we have chosen to work with the former type of spatial arrangement as Gérard et al. (2010) show tax interactions in Belgium only occur between close neighbours. Thus, we use a first-order contiguity matrix. This matrix is row-normalised in such a way that each element of the vector $\mathbf{W} T_{t}$ represents the average tax rates of the municipalities which are considered as neighbours to a given municipality.

$N_{t}$ is a vector that contains the number of parties in the government of each municipality. It takes into account the context of political responsibility of the local jurisdiction. One can assume that voters will punish more strongly single-party governments than multi-parties ones because the responsibility is clearer in those governments. In addition, coalition governments blur the responsibility of individual parties for whom the voter must vote and offer thus a possibility of vote switching within the government (Powell and Whitten, 1993).

Bosch and Sollé-Ollé (2007) estimate another vote function. They do not include all variables in level but some are in differences. The election results are then depending on the evolution of tax rates (and socio-economics variables) rather than on their level. We will name it the "difference I" model. It is written:

$$
V_{t}=\alpha V_{t-1}+\left(\mathbf{X}_{t}-\mathbf{X}_{t-1}\right) \beta+\delta\left(T_{t}-T_{t-1}\right)+\lambda \mathbf{W}\left(T_{t}-T_{t-1}\right)+\gamma N_{t}+\varepsilon_{t}
$$

A common element of both specifications is that there is no variable measuring the difference of taxation between local jurisdictions and their neighbours, although such a variable is underlying the yardstick voting hypothesis. Therefore, one can test two other specifications. The first, in Eq. 3, extends the "level I" model. We will name it the "level II" model.

$$
V_{t}=\alpha V_{t-1}+\mathrm{X}_{t} \beta+\delta T_{t}+\lambda\left(T_{t}-\mathbf{W} T_{t}\right)+\gamma N_{t}+\varepsilon_{t}
$$

The second one (Eq. 4) extends the "difference I" model. We will name it the "difference II" model.

$$
\begin{aligned}
& V_{t}=\alpha V_{t-1}+\left(\mathbf{X}_{t}-\mathbf{X}_{t-1}\right) \beta+\delta\left(T_{t}-T_{t-1}\right)+\lambda\left[\left(T_{t}-T_{t-1}\right)-\mathbf{W}\left(T_{t}-T_{t-1}\right)\right] \\
& +\gamma N_{t}+\varepsilon_{t}
\end{aligned}
$$

The estimation of a vote function raises an endogeneity issue since incumbents can act opportunistically and adapt their tax policy according to their popularity (Revelli, 2002). Then, the tax variables $T_{t}$ may be correlated with the error terms. This would bias the results. To overcome this problem, we follow the literature on vote-function. We instrument the tax variables and use 2SLS.

We may also suspect the residuals to be spatially autocorrelated because of the presence of spatial variables in the equations. We compute the Moran's I on the residuals in order to test for spatial autocorrelation. The null hypothesis of absence of spatial autocorrelation is not rejected. In the same way, Hausman endogeneity tests conclude that these variables can be considered as exogenous. 


\section{Data}

We study the election results of the most recent local election that occurred in the Walloon Region (October 14, 2012). We collected the vote share of the party (parties) that was (were) in the local government during the legislature that came to an end. When a coalition ruled the municipality, we sum up the vote shares to obtain the total one. We retain the number of parties which were making up the government. The vote share at the previous election was also collected. When we were not able to find a party, we compared the candidate names of the lists in order to find whether the party changed its name between the two elections. In that case, we retain the vote share of the party with the new name. Vermeir and Heyndels (2006) only consider the cases where government parties participate in the elections with the same name. However, we think that this approach is too restrictive in the sense that the new names of the parties are very similar to the old ones in most cases. In addition, the lists are driven by a leading figure that is identifiable for voters. Therefore, we do not think that the name change affects the potential yardstick voting. However, we dropped observations because we can not identify some new list names. Our total number of municipalities is 237.

Two local tax rates were considered: the local surcharges on income tax and the local surcharges on property tax. They account for about 80 percent of their tax revenue and 40 percent of their total revenue. The local council is free to decide their level. To instrument them, we firstly test whether the potential instruments are still correlated with tax rates when explanatory variables are taken into account (Wooldridge, 2006). Then, we conduct Sargan tests for overidentying restrictions. This procedure leads us to use different instruments in each model (Table 1).

Table 1 . Summary statistics of the variables

\begin{tabular}{|c|c|}
\hline Model & Instruments \\
\hline Level 1 & House prices, median income per tax return, unemployment rate \\
\hline Level 2 & House prices, unemployment rate, proportion of new housing \\
\hline Difference 1 & $\begin{array}{l}\text { First difference in house prices, in median income per tax return and in } \\
\text { unemployment rate }\end{array}$ \\
\hline Difference 2 & $\begin{array}{l}\text { First difference in house prices, in median income per tax return and in } \\
\text { unemployment rate, proportion of new housing, population density }\end{array}$ \\
\hline
\end{tabular}

All instruments are socio-demographic variables. Because we use these variables as instruments, we finally decide to not include socio-demographic variables in our models. We made several estimations with one of these variables as explanatory variable of vote share and the other as instruments for tax rates. We do not find significant effects. This result is in conformity with the literature. We try to find other instruments but they failed at our statistical tests. Therefore, we have preferred to use a maximum of instruments for tax rates because it allows to perform Sargan tests and to produce better 2SLS estimators.

Table 2 reports the summary statistics of the data. 
Table 2. Summary statistics of the variables

\begin{tabular}{|c|c|c|c|c|c|c|}
\hline Explanatory variables & Source & Unit & Mean & $\begin{array}{l}\text { Standard } \\
\text { deviation }\end{array}$ & Min & Max \\
\hline Vote share in 2012 & $\begin{array}{l}\text { Website of the } \\
\text { election }\end{array}$ & $\%$ & 59.27 & 12.24 & 20.62 & 88.12 \\
\hline Vote share in 2006 & $\begin{array}{l}\text { Website of the } \\
\text { election }\end{array}$ & $\%$ & 59.89 & 8.95 & 39.2 & 84.79 \\
\hline Local surcharges on income tax & Walloon Region & $\%$ & 7.72 & 0.84 & 5.7 & 8.8 \\
\hline Neighbor's local surcharges on income tax & Wallon Region & $\%$ & 7.71 & 0.60 & 5.95 & 8.65 \\
\hline Local surcharges on property tax & Walloon Region & Centimes & 2513.67 & 300.75 & 1200 & 3100 \\
\hline Neighbor's local surcharges on property tax & $\begin{array}{l}\text { Walloon Region } \\
\text { Calculated based } \\
\text { on data of the } \\
\text { Center for Socio- } \\
\text { Political Research }\end{array}$ & Centimes & 2522.80 & 206.04 & 1625 & 2912.5 \\
\hline Number of parties in the local governments & $\begin{array}{l}\text { and Information } \\
\text { Belgian National } \\
\text { Institute of }\end{array}$ & - & 1.47 & 0.59 & 1 & 3 \\
\hline Median income per tax return & $\begin{array}{l}\text { Statistics } \\
\text { Walloon Institute } \\
\text { for evaluation, } \\
\text { forecast and }\end{array}$ & Euro & 38016.54 & 5511.462 & 25019 & 55394 \\
\hline Unemployment rate & $\begin{array}{l}\text { statistics } \\
\text { Walloon Institute } \\
\text { for evaluation, } \\
\text { forecast and }\end{array}$ & $\%$ & 12.99 & 4.71 & 3.64 & 27.37 \\
\hline House prices & statistics & Euro & 162625.19 & 47275.849 & 93944 & 478265 \\
\hline $\begin{array}{l}\text { Differences in median income per tax } \\
\text { return (2010-2006) }\end{array}$ & Own calcul. & Euro & 4520,30 & 1015,46 & 1708 & 7287 \\
\hline Differences in unemployment rate & Own calcul. & $\%$ & -1.42 & 1.03 & -4.57 & 1.26 \\
\hline Population density & $\begin{array}{l}\text { Belgian National } \\
\text { Institute of } \\
\text { Statistics } \\
\text { Walloon Institute } \\
\text { for evaluation, } \\
\text { forecast and }\end{array}$ & $\mathrm{Inh} / \mathrm{Km}^{2}$ & 329.40 & 448.39 & 24.153 & 3328.52 \\
\hline Percentage new housing & statistics & $\%$ & 11.61 & 4.13 & 3.00 & 27.20 \\
\hline
\end{tabular}

Note: We do not have data for unemployment rates and median income per tax return for 2012. Therefore, we have used data for 2010.

\section{Results}

Table 3 reports the results of the estimations. Four models are estimated by both OLS and 2SLS. The comparison shows that the "difference" models explain our data better. The fits are higher. This suggests that the evolution of tax rates matters more for voters than their level. The results do not allow to discriminate between the "I" and "II" models.

The vote share at the previous election is significant in all models. The magnitude of its coefficient is also stable. This shows the persistency of votes across the elections. The number of parties in the local government is also significant and positive. This result is in line with the 
theory stating that in coalition the responsibility of individual parties is blurred. They are also in line with the empirical literature on vote function.

None of the own tax variables is significant in the "level" models. On the contrary, the own local surcharges on income tax is significant and negative in the "difference" models when they are estimated using OLS. The negative value of this variable is expected. As in these models this variable is expressed in differences, this suggests that voters punished their incumbents when they increase local income tax rates. Their evolution thus matters, not their level (as in the "level" models). However, the variable is no longer significant when the equations are estimated by 2SLS.

The neighbour's tax variables test for yardstick voting. In the "I" models, a positive sign of these variables is expected. Its magnitude is also expected to be higher than the coefficient of own tax rates. In that way, it would indicate that voters reward their incumbents for tax rates lower than in the neighbourhood. On the contrary, in the "II" models, a significant negative sign is expected since the variable is the difference between own tax rates and those in the neighbourhood. Our estimators do not always have the expected sign. The positive sign of this variable in the "difference II" model may be interpreted as follows. Voters may reward incumbents for higher expenditures since higher tax rates may mean higher revenue and hence higher expenditures. This reward is nonetheless lower than the punishment of rising local income tax rates.

However, none of neighbour's tax variables is statistically significant. This result suggests tax rates of neighbouring jurisdictions do not influence voters. This result is in contradiction with those of Vermeir and Heyndels (2006) for the Flemish Region. They are in line with Bordignon et al. (2002). Dubois and Paty (2010) also do not find significant effects of neighbouring tax rates when the neighbouring jurisdictions are defined on a sole geographical criterion. 
Table 3. Estimation results

\begin{tabular}{|c|c|c|c|c|c|c|c|c|}
\hline \multirow{2}{*}{ Variable } & \multicolumn{2}{|c|}{ "Level I" } & \multicolumn{2}{|c|}{ "Level II" } & \multicolumn{2}{|c|}{ "Difference I" } & \multicolumn{2}{|c|}{ "Difference II" } \\
\hline & OLS & 2SLS & OLS & 2SLS & OLS & 2SLS & OLS & 2SLS \\
\hline Intercept & $\begin{array}{l}18.17 * \\
(1.63)\end{array}$ & $\begin{array}{c}3.4 \\
(0.15)\end{array}$ & $\begin{array}{l}18.17 * \\
(1.63)\end{array}$ & $\begin{array}{l}17.47 \\
(0.91)\end{array}$ & $\begin{array}{l}16.57 * * * \\
(3.39)\end{array}$ & $\begin{array}{l}19.92 * * * \\
(2.85)\end{array}$ & $\begin{array}{c}16.57 * * * \\
(-8.29)\end{array}$ & $\begin{array}{c}16.20 * * * \\
(-3.22)\end{array}$ \\
\hline Vote share in 2006 & $\begin{array}{c}0.63 * * * \\
(8.05)\end{array}$ & $\begin{array}{l}0.62 * * * \\
(5.6)\end{array}$ & $\begin{array}{c}0.63 * * * \\
(8.05)\end{array}$ & $\begin{array}{c}0.63 * * * \\
(8.04)\end{array}$ & $\begin{array}{c}0.66 * * * \\
(8.29)\end{array}$ & $\begin{array}{l}0.56 * * * \\
(3.69)\end{array}$ & $\begin{array}{c}0.66 * * * \\
(-8.29)\end{array}$ & $\begin{array}{c}0.65 * * * \\
(-7.25)\end{array}$ \\
\hline Own local surcharges on income tax & $\begin{array}{l}1.23 \\
(1.01)\end{array}$ & $\begin{array}{l}16.26 \\
(1.14)\end{array}$ & $\begin{array}{l}1.46 \\
(0.91)\end{array}$ & $\begin{array}{l}2.29 \\
(0.49)\end{array}$ & $\begin{array}{r}-3.17 * * \\
(-1.93)\end{array}$ & $\begin{array}{l}-2.13 \\
(-0.18)\end{array}$ & $\begin{array}{l}-6.47^{*} \\
(-1.67)\end{array}$ & $\begin{array}{l}-3.94 \\
(-0.29)\end{array}$ \\
\hline $\begin{array}{l}\text { Neighbor's local surcharges on } \\
\text { income tax }\end{array}$ & $\begin{array}{l}0.23 \\
(0.13)\end{array}$ & $\begin{array}{c}-9.24 \\
(-0.98)\end{array}$ & $\begin{array}{l}-0.23 \\
(-0.13)\end{array}$ & $\begin{array}{l}-0.90 \\
(-0.23)\end{array}$ & $\begin{array}{l}3.29 \\
(0.91)\end{array}$ & $\begin{array}{l}6.05 \\
(1.13)\end{array}$ & $\begin{array}{l}3.29 \\
(0.91)\end{array}$ & $\begin{array}{c}1.17 \\
(0.91)\end{array}$ \\
\hline Own local surcharges on property tax & $\begin{array}{c}-0.00 \\
(-1.13)\end{array}$ & $\begin{array}{c}-0.05 \\
(-1.41)\end{array}$ & $\begin{array}{c}-0.00 \\
(-1.08)\end{array}$ & $\begin{array}{c}-0.01 \\
(-0.69)\end{array}$ & $\begin{array}{c}-0.00 \\
(-0.47)\end{array}$ & $\begin{array}{c}0.02 \\
(0.64)\end{array}$ & $\begin{array}{c}0.00 \\
(0.62)\end{array}$ & $\begin{array}{c}0.01 \\
(0.23)\end{array}$ \\
\hline $\begin{array}{l}\text { Neighbor's local surcharges on } \\
\text { property tax }\end{array}$ & $\begin{array}{l}-0.00 \\
(-0.17)\end{array}$ & $\begin{array}{c}0.04 \\
(-1.26)\end{array}$ & $\begin{array}{c}0.00 \\
(0.17)\end{array}$ & $\begin{array}{c}0.00 \\
(0.30)\end{array}$ & $\begin{array}{c}0.01 \\
(0.91)\end{array}$ & $\begin{array}{l}-0.00 \\
(-1.13)\end{array}$ & $\begin{array}{c}-0.01 \\
(-0.91)\end{array}$ & $\begin{array}{l}-0.01 \\
(-0.31)\end{array}$ \\
\hline $\begin{array}{l}\text { Number of parties in the local } \\
\text { government }\end{array}$ & $\begin{array}{l}3.19 * * * \\
(2.65)\end{array}$ & $\begin{array}{l}4.12 * * \\
(2.21)\end{array}$ & $\begin{array}{c}3.18 * * * \\
(2.64)\end{array}$ & $\begin{array}{c}3.15 * * * \\
(2.60)\end{array}$ & $\begin{array}{l}2.63 * * \\
(2.19)\end{array}$ & $\begin{array}{l}3.63^{*} \\
(1.65)\end{array}$ & $\begin{array}{l}2.63 * * \\
(2.19)\end{array}$ & $\begin{array}{l}2.65^{* * *} \\
(2.1)\end{array}$ \\
\hline Adjusted $\mathrm{R}^{2}$ & 0.24 & 0.14 & 0.24 & 0.24 & 0.25 & 0.18 & 0.25 & 0.25 \\
\hline Breusch-Pagan test (p value) & 0.23 & 0.87 & 0.57 & 0.60 & 0.74 & 0.71 & 0.74 & 0.72 \\
\hline Moran's I of the residuals ( $\mathrm{p}$ value) & 0.47 & 0.79 & 0.28 & 0.25 & 0.28 & 0.20 & 0.28 & 0.14 \\
\hline Sargan test (p value) & - & 0.34 & - & 0.15 & - & 0.25 & - & 0.17 \\
\hline
\end{tabular}

Notes: (i) t-values are in parentheses; (ii) Two-tailed t-test significant at *0.10**0.05***0.01. 


\section{Conclusion}

This paper aims at testing yardstick competition by testing its seminal hypothesis: yardstick voting. In fact, the yardstick competition theory states that local incumbents are mimicking each other because they fear not to be re-elected. This implies that they fear punishment for implementing higher tax rates than in the neighbouring jurisdictions. The research question of this paper is thus: do voters punish their incumbents for higher tax rates?

To achieve this objective, we use data about the most recent local election that took place in the Walloon region and estimate a vote function. Such a function relates the election results to socio-economics characteristics of local jurisdictions and tax rates, including those of neighbouring jurisdictions. We test for four different specifications. Each of them differs in the way we include tax variables: in absolute value, in difference, or in difference compared to the neighbourhood.

None of our tested specifications supports the yardstick voting hypothesis. This result is in line with part of the literature. Therefore, one can exclude yardstick voting as a statistically supported behaviour of local taxpayers. Further one can exclude yardstick competition as a source of tax interactions in the Walloon region, if yardstick voting is a testable hypothesis of yardstick competition. Indeed, if the tax rates of the neighbouring jurisdictions do not influence voters' choices, incumbents do not have to fear an electoral punishment and then mimicking each other is meaningless.

However, in this paper we use a strict geographical criterion to define neighbourhood. Dubois and Paty (2010) show that voters are comparing tax increases in their jurisdiction with those in jurisdictions that are similar in terms of demographic characteristics. It may be relevant to test for different definitions of neighbourhood in the Walloon Region. This would be a natural extension in the empirical search for yardstick competition.

Acknowledgements. The authors are indebted to Francisco J. Delgado and a referee for helpful comments and suggestions.

\section{References}

Besley, T. and Smart M. (2007) Fiscal restraints and voter welfare, Journal of Public Economics, 91(3-4), 755-773.

Bordignon, M., Cerniglia F. and Revelli F. (2002) In search for yardstick competition: property tax rates and electoral behaviour in Italian cities, CESifo Working Paper, No. 644.

Bosch, N. and Solé-Ollé A. (2007) Yardstick competition and the political costs of raising taxes: an empirical analysis of Spanish municipalities, International Tax and Public Finance, 14(1), 71-92.

Delgado, F.J., Lago, S. and Mayor, M. (2011) On the determinants of local tax rates: new evidence from Spain, Working Paper IEB 2011/4, Institut d'Economia de Barcelona, Barcelona.

Dubois, E. and Paty, S. (2010) Yardstick competition: which neighbours matter?, Annals of Regional Science, 44, 433-452.

Elhorst, J.-P. and Fréret, S. (2009) Evidence of political yardstick competition in France using a two-regime spatial Durbin model with fixed effects, Journal of Regional Science, 49(5), 931-951. 
Feld, L., Josselin, J.M. and Rocaboy, Y. (2003) Tax mimicking among regional jurisdictions, in Marciano A. and Josselin, J.M. (eds): From economic to legal competition. New perspectives on law and institutions in Europe, Edgar Elgar: London, 105-119.

Gérard, M., Jayet, H. and Paty, S. (2010) Tax interactions among Belgian municipalities: do interregional differences matter?, Regional Science and Urban Economics, 40, 336-342.

Gérard, M. and Van Malderen, L. (2012) Tax interactions among Walloon municipalities: is there room for yardstick competition, intellectual trend and partisan monopoly effect?, CESIFO Working Paper, No. 4025.

Heyndels, B. and Vuchelen, J. (1998) Tax mimicking among Belgian municipalities, National Tax Journal, 51, 89-101.

Powell, G.B. and Whitten, G.D. (1993) A cross-national of economic voting: taking account of the political context, American Journal of Political Science, 37(2), 391-414.

Revelli, F. (2002) Local taxes, national politics and spatial interactions in English district election results, European Journal of Political Economy, 18, 281-299.

Revelli, F. (2005) On spatial public finance empirics, International Tax and Public Finance, $12(4), 475-492$.

Richard, J., Tulkens, H. and Verdonck, M. (1997) Dynamic of fiscal interactions among Belgian municipalities, 1984-1997, Economie et Prévision, 2002/5(156), 1-14.

Santolini, R. (2008) A spatial cross-sectional analysis of electoral trends in Italian municipalities, Papers in Regional Science, 87(3), 431-451.

Salmon, P. (2013) How significant is yardstick competition among governments? Three reasons to dig deeper, Working Paper hal-00830872, HAL.

Vermeir, J. and Heyndels, B. (2006) Tax policy and yardstick voting in Flemish municipal elections, Applied Economics 38(19), 2285-2298.

Wooldridge, J. (2006) Introductory econometrics - A modern approach, third edition, South Western: Mason. 